Original article

\title{
Epidemiology and risk factors of Helicobacter pylori infection in Timergara city of Pakistan: A cross-sectional study
}

\author{
Syed Rafiq Hussain Shah ${ }^{\text {a,b,*, Babiker Saad Almugadam }}{ }^{\text {a,c, }{ }^{* *}, \text { Akbar Hussain }}{ }^{\text {b,d }}$, \\ Tauseef Ahmad $^{\text {b,e }}$, Shehzad Ahmed ${ }^{\text {b }}$, Shahida Sadiqui ${ }^{\text {b }}$ \\ ${ }^{a}$ Department of Microecology, Collage of Basic Medical Sciences, Dalian Medical University, Dalian, China \\ ${ }^{\mathrm{b}}$ Department of Microbiology, Hazara University, Mansehra, 21300, Khyber Pakhtunkhwa, Pakistan \\ ${ }^{\mathrm{c}}$ Department of Microbiology, Faculty of Medical Laboratory Sciences, University of El Imam El Mahdi, Kosti, Sudan \\ d Department of Microbiology, Collage of Basic Medical Sciences, Dalian Medical University, Dalian, China \\ ${ }^{\mathrm{e}}$ Department of Epidemiology and Health Statistics, School of Public Health, Southeast University, Nanjing, 210009, China
}

\section{A R T I C L E I N F O}

\section{Keywords:}

Blood group

H. pylori

Risk factors

Pakistan

Prevalence

\begin{abstract}
A B S T R A C T
Objective: $H$. pylori infection remains a major public health challenge. Our study aimed to determine the prevalence of $H$. pylori infection among the local population of the Timergara city in Lower Dir District of Pakistan and investigating the common risk factors associated with disease development. Methods: Between September 2016 to January 2017, 520 individuals have involved in this study. A venous blood sample along with questionnaire data was collected from each participant and $H$. pylori infection investigated using Indirect EnzymeLinked ImmunoSorbent Assay. Results: Out of 520 persons studied, $115(22.1 \%)$ were positive and 405 (77.9\%) were negative. The majority of infected individuals were males $79(29.4 \%)$ compared to females 34 (14.3\%), P value<0.000. The probability of $H$. pylori infection was more among smokers 32 (33\%), snuff addictive 29 (35.8\%), and regular soft drinks takers 57 (43.5\%). Furthermore, the logistic regression revealed that the odds of developing $H$. pylori infection were significantly higher in males (AOR:2.1, 95\%CI:1.0-4.7), smokers (AOR:1.7, 95\%CI:0.4-2.1), snuff addiction (AOR:5.5, 95\%CI:1.2-24.1), no regular toothpaste users (AOR:16.1, 95\%CI:8.7-29.8), and regularly soft drinks takers (AOR:4.5, 95\%CI:1.7-12.0). Likewise, it was greater in no formal (AOR:3.3, 95\%CI:3.7-2.9), primary school (AOR:1.7,95\%CI:0.0-0.0), and secondary school (AOR:5.5,95\%:2.3-13.2) educated persons compared to individuals of University education level. Conclusions: Our study has highlighted the epidemiology and risk factors associated with $H$. pylori infection in Timergara city and revealed the need for further studies to a better understanding of the epidemiology of $H$. pylori infection, which is helpful in diagnosis and prevention of disease.
\end{abstract}

\section{Introduction}

Helicobacter pylori is a microaerophilic pathogen that affects about half of the world populations. Globally, it is a common cause of gastritis, peptic ulcer, gastric ulcer, and gastric carcinoma. ${ }^{1,2}$ Approximately, $50 \%$ of the world populations are seropositive for $H$. pylori. ${ }^{1}$ In the industrialized countries, the prevalence of $H$. pylori infection has diminished markedly. ${ }^{3}$ Moreover, the frequency of $H$. pylori is often considerably greater among first- and second-generation immigrants from the developing world to western countries. ${ }^{3,4}$ Previously, it has been estimated that people who tested positive to $H$. pylori have a $10-20 \%$ increased risk of developing peptic ulcer disease and a $1-2 \%$ increased risk of developing distal gastric cancer. Likewise, the World Health Organization has declared $H$. pylori as a Class 1 carcinogen. ${ }^{5}$

On red blood cells, the blood group antigens are permanent, fixed and life-lasting biological markers. ${ }^{6}$ Earlier studies have linked the ABO phenotype with stomach ulcers and gastric cancer, which are more common in individuals who carry blood group $\mathrm{O}$ and $\mathrm{A}$, respectively. H. pylori enter the digestive tract through the mouth and reach the gastric mucosa, where it causes an infection that is closely associated

\footnotetext{
* Corresponding author. Department of Microecology, Collage of Basic Medical Sciences, Dalian Medical University, Dalian, China.

** Corresponding author. Department of Microbiology, Faculty of Medical Laboratory Sciences, University of El Imam El Mahdi, Kosti, Sudan.

E-mail addresses: syedrafiq223@gmail.com (S.R. Hussain Shah), Babiker888@yahoo.com (B.S. Almugadam), akbarhusain1@gmail.com (A. Hussain), tahmad222@seu.edu.cn (T. Ahmad), syedrafiq223@gmail.com (S. Ahmed), shah23@gmail.com (S. Sadiqui).
} 
with the development of gastric ulcer. ${ }^{1,7,8}$ It is also reported that the binding of bacteria to blood group antigens expressed on the surface of the gastric mucosa plays a key role in the persistence of infection. ${ }^{1}$ Typically, around $90 \%$ of infected individuals do not have clinical indications or complications of the illness. ${ }^{9}$ However, untreated H. pylori infection can last a lifetime leading to chronic gastritis, which can develop into ulcer and carcinoma. This introduces the need for early diagnosis and proper disease therapy. Furthermore, $H$. pylori infection is also associated with the increased risk for gastric mucosal-associated lymphoid tissues (MALT) lymphoma in the infected individuals. ${ }^{10}$ Understanding the occurrence of $H$. pylori infection and its interaction with socio-demographic factors is important in identifying the pathology and epidemiology of the disease. Thus, the present study aims to determine the prevalence of $H$. pylori among the local population of Timergara city in the Lower Dir District of Pakistan through serological techniques and investigate the common risk factors associated with the development of the disease.

\section{Materials and methods}

\subsection{Study design, duration, and area}

This was a cross-sectional study conducted from September 2016 to January 2017 at Timergara city, Pakistan. Timergara is the district headquarters of Lower Dir District. The population of the study area consists of heterogeneous groups of different tribes. The major occupations are farmers, labor, and employee. Ethical approval from the Advanced Studies and Research Board in Hazara University has been obtained and informed written consent was taken from all participants in the study. The local authority of the Lower Dir District also gave permission. The study protocols have conducted according to the guidelines of the Declaration of Helsinki for the research regarding human subjects.

\subsection{Sample size}

To determine the prevalence of $H$. pylori infection in Timergara city, the sample size was estimated based on the expected probability of disease as determined by a preliminary study. The following equation was used:

$\mathrm{n}=\mathrm{Z}^{2} \times \mathrm{P}(\mathrm{P}-1) / \mathrm{d}^{2}$

n: Sample size, Z: The value of the standard normal variable corresponding to $95 \%$ level of significance $=1.96$, P: Expected prevalence as determined by pilot study $=17 \%$, d: The precision (corresponding to the effect size) $=0.05$.

Accordingly,

$\mathrm{n}=(1.96)^{2} \times 0.17(0.17-1) /(0.05)^{2}=217.8$

Although the calculated sample size is 217 , the researchers have recorded the entire investigation of positive respondents during the study duration to obtain more accurate findings.

\subsection{Study subject and data collection}

The study subjects included people suspected to have $H$. pylori infection as determined by physical examination and medical history. Accordingly, only the people (consecutive samples and age range 11-70 years) who visited the outpatient clinics, health care centers, and hospitals in Timergara city were enrolled. The individuals who suffered from kidney or heart disease; alcoholics; and those who have a past medical history of GIT surgery, radio or chemotherapy, hypertension, diabetes mellitus or other chronic diseases, or antimicrobial use before 2 weeks of the study were excluded. Pregnant and breastfeeding females were also excluded. Researchers invited the contributors and explained the protocol of the study. Participant's characteristics including age, gender, education level, and socioeconomic status were gathered using a constructed questionnaire. Additionally, the study contributors were also kindly asked about the smoking, snuff addiction, regular soft drinks consumption and toothpaste using to test the evidence of their association with $H$. pylori infection. ${ }^{11-14}$

\subsection{Samples collection and laboratory investigations}

The venous blood sample $(6-8 \mathrm{ml})$ was collected from each subject. Immediately, every sample was divided into 2 containers (EDTA, Plain $=$ without anticoagulant). Plain blood container samples were allowed to clot at room temperature, then centrifuged at $3000 \mathrm{rpm}$ for $5 \mathrm{~min}$ to obtain serum, which was transferred into a sterile Eppendorf tube and stored at $-20{ }^{\circ} \mathrm{C}$ until further analysis.

Blood group and Rhesus factor of participants were investigated by a conventional hem-agglutination test using the anti-sera kits (DIAGAST, France) and EDTA blood samples. To verify the weak or negative D reaction, the Du method was performed. Furthermore, $H$. pylori infection was determined by the detection of anti-H. pylori (IgG) titer in patients serum using Indirect Enzyme-Linked ImmunoSorbent Assay (I-ELISA) according to company protocol (Abcam, UK). ELISA Kit has a $92 \%$ specificity and $94.4 \%$ sensitivity. Moreover, all ELISA conditions were performed in duplicate and each sample with a mean IgG titter of more than $20 \mathrm{U} / \mathrm{ml}$ was reported as positive (reactive) for $H$. pylori infection.

\subsection{Data analysis}

The study data was entered in Microsoft excel and a duple check by a different analyst was adapted to ensure the successful data input. Statistical analysis of the study findings was performed using the Statistical Package for Social Sciences (SPSS) software, version 21. The research results were expressed as numbers and percentages. Chi-squared and Fishers Exact tests were adopted to evaluate the difference between study variables. Using binary logistic regression model, crude odds ratios and $95 \%$ confidence intervals were measured. Furthermore, to determine the strength of the associations between $H$. pylori infection and potential risk factors, the adjusted odds ratio was also calculated by adjusting all the univariate variables together as well as the multivariate variables with each other. A P value of less than 0.05 was considered significant.

\section{Results}

\subsection{Socio-demographic characteristics of the study contributors}

520 individuals with age Mean \pm SD $36.4 \pm 15.2$ years (Minimum $=$ 11 , Maximum $=68$ ) were included. As seen in Table 1 , the majority of study contributors were 11-30 years old 308 (59.2\%), non-smokers 423 $(81.3 \%)$ or snuff addictive $439(84.4 \%)$, urbanized areas residents 437 (84\%), non-regularly soft drinks takers 389 (74.8\%), and regular toothpaste users $361(69.4 \%)$. Based on blood group and rhesus typing, the majority of participants were B + ve 140 (26.9\%), A + ve 135 (26\%) and $A B+$ ve 94 (18.1\%), besides, most of them 451 (86.7\%) exhibited a positive rhesus type. Additionally, most of the study individuals had high education levels and middle monthly income (Table 1).

\subsection{The prevalence of $H$. Pylori infection}

Out of 520 individuals, 115 (22.1\%) were positive and 405 (77.9) were negative for $H$. pylori infection (Fig. 1 ). The probability of $H$. pylori infection was significantly much higher in males 79 (29.4\%), smokers 32 (33\%), snuff addictives 29 (35.8\%), regular soft drinks takers 57 (43.5\%), and non-regular toothpaste user 83 (52.2\%), P values less than 0.005 . On the other hand, a significant variation was also observed in the probability of $H$. pylori infection among the education levels. Indeed, 
Table 1

Characteristics of the study participants.

\begin{tabular}{|c|c|c|}
\hline Variable & & Number (\%) \\
\hline \multirow[t]{2}{*}{ Gender } & Male & $269(51.7)$ \\
\hline & Female & $251(48.3)$ \\
\hline \multirow[t]{3}{*}{ Age } & $11-30$ & $308(59.2)$ \\
\hline & $31-50$ & $178(34.2)$ \\
\hline & $51-70$ & $34(6.6)$ \\
\hline \multirow[t]{3}{*}{ Residence } & Rural & $83(16)$ \\
\hline & Urban & $437(84)$ \\
\hline & No formal & $37(7.1)$ \\
\hline \multirow[t]{3}{*}{ Education level } & Primary school & $69(13.3)$ \\
\hline & Secondary school & $104(20)$ \\
\hline & University & $310(59.6)$ \\
\hline \multirow[t]{3}{*}{ Monthly income } & $\leq 10,000$ & $108(20.8)$ \\
\hline & $11,000-25000$ & $263(50.6)$ \\
\hline & Above 25,000 & $149(28.6)$ \\
\hline \multirow[t]{2}{*}{ Smoking } & Yes & $97(18.7)$ \\
\hline & No & $423(81.3)$ \\
\hline \multirow[t]{2}{*}{ Snuff addiction } & Yes & $81(15.6)$ \\
\hline & No & $439(84.4)$ \\
\hline \multirow[t]{2}{*}{ Regular soft drinks intake } & Yes & $131(25.2)$ \\
\hline & No & $389(74.8)$ \\
\hline \multirow[t]{2}{*}{ Regular toothpaste using } & Yes & $361(69.4)$ \\
\hline & No & $159(30.6)$ \\
\hline \multirow[t]{8}{*}{ Blood group and Rhesus factor } & $\mathrm{O}+\mathrm{ve}$ & $82(15.7)$ \\
\hline & $\mathrm{O}-\mathrm{ve}$ & $27(5.2)$ \\
\hline & $A+v e$ & $135(26)$ \\
\hline & $A-v e$ & $18(3.5)$ \\
\hline & $\mathrm{B}+\mathrm{ve}$ & $140(26.9)$ \\
\hline & $B-v e$ & $18(3.5)$ \\
\hline & $\mathrm{AB}+\mathrm{ve}$ & 94 (18.1) \\
\hline & $\mathrm{AB}-\mathrm{ve}$ & $6(1.1)$ \\
\hline \multirow[t]{2}{*}{ Rhesus factor } & Positive & 451 (86.7) \\
\hline & Negative & $69(13.3)$ \\
\hline
\end{tabular}

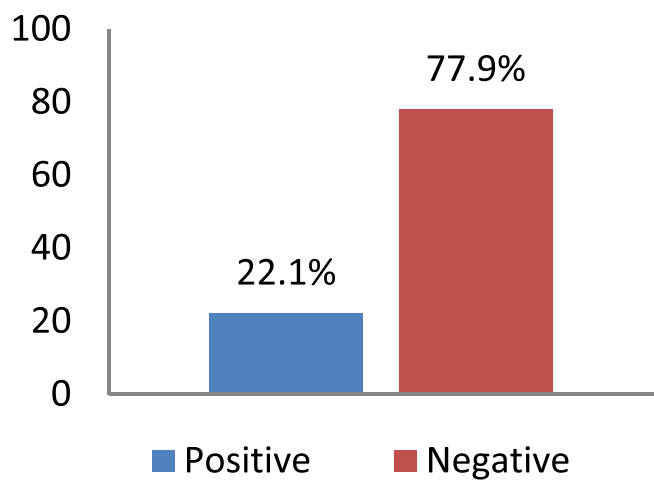

Fig. 1. Prevalence of $H$. pylori infection in Timergara city.

the non-formal and primary school educated patients represented the majority of the infected individuals (Chi-squared:60.728, P value $<0.000$ ). Moreover, there was no significant difference in the occurrence of $H$. pylori infection among age groups, residence, income levels, and blood groups and Rhesus types, P values more than 0.05 (Table 2).

\subsection{Common associated factors with $H$. Pylori infection}

The logistic regression model revealed that the odds of developing $H$. pylori infection were significantly higher in males (AOR:2.1, 95\% CI:1.0-4.7), smokers (AOR:1.7, 95\%CI:0.4-2.1), snuff addictive (AOR:5.5, 95\%CI:1.2-24.1), no regular toothpaste users (AOR:16.1, 95\%CI:8.7-29.8), and regularly soft drinks takers (AOR:4.5, 95\% CI:1.7-12.0). Likewise, it was greater in no formal (AOR:3.3, 95\% CI:3.7-2.9), primary school (AOR:1.7, 95\%CI:0.0-0.0), and secondary school (AOR:5.5, 95\%:2.3-13.2) educated persons compared to individuals of University education level. In contrast, it was nonsignificantly lower in 11-30 (AOR:0.4, 95\%CI:0.1-1.1) and 31-50
Table 2

Prevalence of $H$. pylori infection among the study participants.

\begin{tabular}{|c|c|c|c|c|}
\hline \multirow[t]{2}{*}{ Variable } & & \multicolumn{3}{|c|}{ Prevalence } \\
\hline & & N (\%) & $\begin{array}{l}\text { Chi- } \\
\text { squared }\end{array}$ & $P$ value \\
\hline \multirow[t]{2}{*}{ Gender } & Male & $\begin{array}{l}79 \\
(29.4)\end{array}$ & & \\
\hline & Female & $\begin{array}{l}36 \\
(14.3)\end{array}$ & 17.019 & $<0.000$ \\
\hline \multirow[t]{3}{*}{ Age } & $11-30$ & $\begin{array}{l}61 \\
(19.8)\end{array}$ & & \\
\hline & $31-50$ & $\begin{array}{l}44 \\
(24.9)\end{array}$ & 2.850 & $0.235^{\mathrm{f}}$ \\
\hline & $51-70$ & $\begin{array}{l}10 \\
(29.4)\end{array}$ & & \\
\hline \multirow[t]{3}{*}{ Residence } & Urban & $96(22)$ & & \\
\hline & Rural & $\begin{array}{l}19 \\
(22.9)\end{array}$ & 0.035 & 0.853 \\
\hline & No formal & $\begin{array}{l}20 \\
(54.1)\end{array}$ & & \\
\hline \multirow[t]{4}{*}{ Education level } & Primary school & $\begin{array}{l}35 \\
(50.7)\end{array}$ & 60.728 & $<0.000^{\mathrm{f}}$ \\
\hline & Secondary & 17 & & \\
\hline & school & (16.3) & & \\
\hline & University & $\begin{array}{l}43 \\
(13.9)\end{array}$ & & \\
\hline \multirow[t]{3}{*}{ Monthly income } & $\leq 10,000$ & $\begin{array}{l}25 \\
(23.1)\end{array}$ & & \\
\hline & $11,000-25000$ & $\begin{array}{l}52 \\
(19.8)\end{array}$ & 1.898 & 0.391 \\
\hline & Above 25,000 & $\begin{array}{l}38 \\
(25.5)\end{array}$ & & \\
\hline \multirow[t]{2}{*}{ Smoking } & Yes & $32(33)$ & & \\
\hline & No & $\begin{array}{l}83 \\
(19.6)\end{array}$ & 8.186 & 0.004 \\
\hline \multirow[t]{2}{*}{ Snuff addiction } & Yes & $\begin{array}{l}29 \\
(35.8)\end{array}$ & & \\
\hline & No & $\begin{array}{l}86 \\
(19.6)\end{array}$ & 10.435 & 0.001 \\
\hline \multirow[t]{2}{*}{$\begin{array}{l}\text { Regular soft drinks } \\
\text { intake }\end{array}$} & Yes & $\begin{array}{l}57 \\
(43.5)\end{array}$ & & \\
\hline & No & $\begin{array}{l}58 \\
(14.9)\end{array}$ & 46.542 & $<0.000$ \\
\hline \multirow{2}{*}{$\begin{array}{l}\text { Regular toothpaste } \\
\text { using }\end{array}$} & Yes & $32(8.2)$ & & \\
\hline & No & $\begin{array}{l}83 \\
(52.2)\end{array}$ & 1.204 & $<0.000$ \\
\hline \multirow{8}{*}{$\begin{array}{l}\text { Blood group and } \\
\text { Rhesus factor }\end{array}$} & $\mathrm{O}+\mathrm{ve}$ & $18(22)$ & & \\
\hline & $\mathrm{O}-\mathrm{ve}$ & $6(22.2)$ & & \\
\hline & $A+v e$ & $\begin{array}{l}30 \\
(22.2)\end{array}$ & & \\
\hline & $A-v e$ & $4(22.2)$ & & \\
\hline & $\mathrm{B}+\mathrm{ve}$ & $\begin{array}{l}31 \\
(22.1)\end{array}$ & 0.231 & $1.000^{\mathrm{f}}$ \\
\hline & $\mathrm{B}-\mathrm{ve}$ & $4(22.2)$ & & \\
\hline & $\mathrm{AB}+\mathrm{ve}$ & $\begin{array}{l}21 \\
(22.3)\end{array}$ & & \\
\hline & $\mathrm{AB}-\mathrm{ve}$ & 1 (16.7) & & \\
\hline \multirow[t]{2}{*}{ Rhesus factor } & Positive & $\begin{array}{l}100 \\
(22.2)\end{array}$ & & 0.936 \\
\hline & Negative & $\begin{array}{l}15 \\
(21.7)\end{array}$ & 0.007 & \\
\hline
\end{tabular}

Statistical differences were assessed by Pearson Chi-squired and Fisher Exact (f) tests. N: number.

(AOR:0.8, 95\%CI:0.3-2.1) age groups compared to individuals of 51-70 year-old. Furthermore, participants of $\leq 10,000$ and $11,000-25000$ income levels also exhibited a lower risk for $H$. pylori infection, whereas, the rural areas residents were significantly linked to lower susceptibility for $H$. pylori infection (AOR:0.1, 95\%CI:0.0-0.3) compared to individuals of urbanized areas (Table 3).

\section{Discussion}

Internationally, even in modern countries, infectious diseases are a key problem for human health and the environment. Previously, high 
Table 3

Logistic regression analysis for the risk factors of $H$. pylori infection.

\begin{tabular}{|c|c|c|c|c|c|}
\hline \multirow[t]{2}{*}{ Variable } & & \multicolumn{2}{|l|}{ Unadjusted } & \multicolumn{2}{|l|}{ Adjusted } \\
\hline & & $\begin{array}{l}\text { COR }(95 \% \\
\text { CI) }\end{array}$ & $\begin{array}{l}\mathrm{P} \\
\text { value }\end{array}$ & $\begin{array}{l}\text { AOR }(95 \% \\
\text { CI) }\end{array}$ & $\begin{array}{l}\mathrm{P} \\
\text { value }\end{array}$ \\
\hline \multirow[t]{2}{*}{ Gender } & Female & 1 & & 1 & \\
\hline & Male & $\begin{array}{l}2.4 \\
(1.6-3.8)\end{array}$ & $<0.000$ & $\begin{array}{l}2.1 \\
(1.0-4.7)\end{array}$ & 0.047 \\
\hline \multirow[t]{3}{*}{ Age } & $51-70$ & 1 & & 1 & \\
\hline & $11-30$ & $\begin{array}{l}0.5 \\
(0.2-1.3)\end{array}$ & 0.194 & $\begin{array}{l}0.4 \\
(0.1-1.1)\end{array}$ & 0.087 \\
\hline & $31-50$ & $\begin{array}{l}0.7 \\
(0.3-1.7)\end{array}$ & 0.566 & $\begin{array}{l}0.8 \\
(0.3-2.1)\end{array}$ & 0.677 \\
\hline \multirow[t]{4}{*}{ Residence } & Urban & 1 & & 1 & \\
\hline & Rural & $\begin{array}{l}1.0 \\
(0.6-1.8)\end{array}$ & 0.853 & $\begin{array}{l}0.1 \\
(0.0-0.3)\end{array}$ & 0.001 \\
\hline & University & 1 & & 1 & \\
\hline & No formal & $\begin{array}{l}7.3 \\
(3.5-15.0)\end{array}$ & $<0.000$ & $\begin{array}{l}3.3 \\
(3.7-2.9)\end{array}$ & $<0.000$ \\
\hline \multirow[t]{2}{*}{$\begin{array}{l}\text { Education } \\
\text { level }\end{array}$} & $\begin{array}{l}\text { Primary } \\
\text { school }\end{array}$ & $\begin{array}{l}6.3 \\
(3.6-11.3)\end{array}$ & $<0.000$ & $\begin{array}{l}1.7 \\
(0.0-0.0)\end{array}$ & 0.990 \\
\hline & $\begin{array}{l}\text { Secondary } \\
\text { school }\end{array}$ & $\begin{array}{l}1.2 \\
(0.6-2.2)\end{array}$ & 0.535 & $\begin{array}{l}5.5 \\
(2.3-13.2)\end{array}$ & $<0.000$ \\
\hline \multirow{3}{*}{$\begin{array}{l}\text { Monthly } \\
\text { income }\end{array}$} & Above 25,000 & 1 & & 1 & \\
\hline & $\leq 10,000$ & $\begin{array}{l}0.8 \\
(0.4-1.5)\end{array}$ & 0.665 & $\begin{array}{l}0.5 \\
(0.2-1.0)\end{array}$ & 0.084 \\
\hline & $11,000-25000$ & $\begin{array}{l}0.7 \\
(0.4-1.1)\end{array}$ & 0.177 & $\begin{array}{l}0.4 \\
(0.2-0.8)\end{array}$ & 0.018 \\
\hline \multirow[t]{2}{*}{ Smoking } & No & 1 & & 1 & \\
\hline & Yes & $\begin{array}{l}2.0 \\
(1.2-3.2)\end{array}$ & 0.005 & $\begin{array}{l}1.7 \\
(0.4-2.1)\end{array}$ & 0.023 \\
\hline \multirow{2}{*}{$\begin{array}{l}\text { Snuff } \\
\text { addiction }\end{array}$} & No & 1 & & 1 & \\
\hline & Yes & $\begin{array}{l}2.2 \\
(1.3-3.8)\end{array}$ & 0.002 & $\begin{array}{l}5.5 \\
(1.2-24.1)\end{array}$ & 0.021 \\
\hline \multirow{3}{*}{$\begin{array}{l}\text { Regular soft } \\
\text { drinks } \\
\text { intake }\end{array}$} & No & & & & \\
\hline & Yes & 1 & & 1 & \\
\hline & & $\begin{array}{l}4.3 \\
(2.8-6.8)\end{array}$ & $<0.000$ & $\begin{array}{l}4.5 \\
(1.7-12.0)\end{array}$ & 0.002 \\
\hline \multirow{2}{*}{$\begin{array}{l}\text { Regular } \\
\text { toothpaste } \\
\text { using }\end{array}$} & Yes & 1 & & 1 & \\
\hline & No & $\begin{array}{l}11.2 \\
(6.9-18.1)\end{array}$ & $<0.000$ & $\begin{array}{l}16.1 \\
(8.7-29.8)\end{array}$ & $<0.000$ \\
\hline \multirow{8}{*}{$\begin{array}{l}\text { Blood group } \\
\text { and } \\
\text { Rhesus } \\
\text { factor }\end{array}$} & $\mathrm{AB}-\mathrm{ve}$ & 1 & & 1 & \\
\hline & $\mathrm{AB}+\mathrm{ve}$ & $\begin{array}{l}1.4 \\
(0.1-12.9)\end{array}$ & 0.746 & $\begin{array}{l}1.5 \\
(0.1-14.8)\end{array}$ & 0.717 \\
\hline & $\mathrm{O}+\mathrm{ve}$ & $\begin{array}{l}1.4 \\
(0.1-12.8)\end{array}$ & 0.762 & $\begin{array}{l}1.3 \\
(0.1-12.6)\end{array}$ & 0.774 \\
\hline & $\mathrm{O}-$ ve & $\begin{array}{l}1.4 \\
(0.1-14.6)\end{array}$ & 0.764 & $\begin{array}{l}1.4 \\
(0.1-14.5)\end{array}$ & 0.776 \\
\hline & $A+v e$ & $\begin{array}{l}1.4 \\
(0.1-12.7)\end{array}$ & 0.749 & $\begin{array}{l}1.4 \\
(0.1-12.5)\end{array}$ & 0.761 \\
\hline & $A-v e$ & $\begin{array}{l}1.4 \\
(0.1-16.0)\end{array}$ & 0.772 & $\begin{array}{l}1.4 \\
(0.1-15.8)\end{array}$ & 0.784 \\
\hline & $\mathrm{B}+\mathrm{ve}$ & $\begin{array}{l}1.4 \\
(0.1-12.6)\end{array}$ & 0.752 & $\begin{array}{l}1.3 \\
(0.1-12.4)\end{array}$ & 0.764 \\
\hline & B - ve & $\begin{array}{l}1.4 \\
(0.1-16.0)\end{array}$ & 0.772 & $\begin{array}{l}1.4 \\
(0.1-15.8)\end{array}$ & 0.784 \\
\hline \multirow{2}{*}{$\begin{array}{l}\text { Rhesus } \\
\text { factor }\end{array}$} & Positive & 1 & & 1 & \\
\hline & Negative & $\begin{array}{l}0.9 \\
(0.5-1.8)\end{array}$ & 0.936 & $\begin{array}{l}0.3 \\
(0.1-0.8)\end{array}$ & 0.016 \\
\hline
\end{tabular}

AOR: adjusted odd ratio, COR: crude odd ratio, CI: confidence interval.

morbidity and mortality due to infectious diseases have been reported globally, particularly, in low-income countries where the majority of the people live within the poverty line. Among these diseases, $H$. pylori infection is a major public health challenge. In past decades, numerous studies have shown the epidemiology, risk factors and transmission modes of $H$. pylori. In Pakistan, little research has been conducted, especially in the Lower Dir District. Epidemiologic studies are necessary to identify the extent and risk factors of sicknesses, which are helpful in diagnosis, therapy, and prevention of diseases. ${ }^{15}$ Our study was conducted to investigate the prevalence of $H$. pylori in Timergara city community using the ELISA technique, which is a noninvasive, useful, simple, cheap, and widely available method. In the current study, the overall reported prevalence of $H$. pylori infection in the community of
Timergara city was $22.1 \%$, which is lower than the prevalence of $34.2 \%$ reported by Khan et al. ${ }^{16}$ in Swat (Pakistan). Moreover, this value is also lower than the previously reported prevalence in several studies. ${ }^{17-20}$ The probable reasons, which could be attributed to the variations in the occurrence of $H$. pylori infection between our study and other study reports, is the difference in the study area and population, socioeconomic conditions, diagnostic methods, and cultural habits, which are known to affect the prevalence and incidence of diseases.

Concerning the socio-demographic characteristics, we found significant variations in the distribution of diseases among gender and education levels. Besides, the observed higher frequency in males and lower education levels in this study, the proportion of $H$. pylori infections were also much higher in smokers, snuff addictive, regular soft drinks takers, and non-regular toothpaste users, with a $\mathrm{P}$ values less than 0.05 . Furthermore, logistic regression analysis showed that the odds of developing the illness is greater in males, low education levels, smokers, non-regular toothpaste users, and regular soft drinks takers. Previous studies have documented similar findings. ${ }^{11,20-22}$ In our study, smoking and snuff addiction were more in males than females, which may affect the occurrence of $H$. pylori infection. Long-term smoking alters the normal physiology of the gastrointestinal tract and affects the factors that protect or heal the lining, including secretion of mucus, blood flow, and production of bicarbonate, which could contribute to its effect on the susceptibility to $H$. pylori infection. Likewise, the association of smoking with peptic ulcers ${ }^{23}$ and the evidence of the relation of $H$. pylori infection with snuff addiction, non-regular toothpaste using, and regular soft drinks consumption might support the findings. ${ }^{12-14}$

Regarding the blood groups and Rhesus factor of our study participants, there was no significant difference in the occurrence of $H$. pylori infection among blood group or Rhesus types, however, most of the previous studies found that people with $\mathrm{O}+$ ve or A + ve are more likely to get illness. ${ }^{24-26}$ This could be attributed to variation in the study area, sample size, and genetic constitutions of the study population.

In the current study, the low small size, shortage of the data of many variables, and lack of the sensitive molecular technique may affect the accuracy and outcome of the findings. Regardless of the limitations, this study is in line with previous studies that have shown the link of our investigated variables with $H$. pylori infection and added more to our knowledge about the epidemiology and risk factors of illness. Likewise, it also suggests that regular toothpaste use together with various enhancements due to education and socioeconomic development, and cultural habits may help in decreasing the risk for $H$. pylori infection.

\section{Conclusion}

In summary, we determined a $22.1 \%$ prevalence of $H$. pylori infection among the symptomatic individuals in the community of Timergara. Smoking, snuff addiction, and regular soft drinks consumption have linked to the risk of disease development. Accordingly, our study has highlighted the prevalence and risk factors associated with $H$. pylori infection in Timergara and revealed the need for further studies to a better understanding of the epidemiology of $H$. pylori infection, which is helpful in diagnosis and prevention of diseases.

\section{Ethical approval}

Ethical approval from the Advanced Studies and Research Board in Hazara University has been obtained. The local authority of the Lower Dir District also gave permission. The study protocols have conducted according to the guidelines of the Declaration of Helsinki for the research regarding human subjects and written informed consent was obtained from all participants.

\section{Funding}

No external had received. 


\section{Declaration of competing interest}

We declare that there was no conflict of interest.

\section{Acknowledgements}

The authors acknowledge the staff and workers of outpatient clinics, health care centers, and hospitals in Timergara city for their support during samples collection. As well, we are very grateful for the study participants.

\section{References}

1 Kao CY, Sheu BS, Wu JJ. Helicobacter pylori infection: an overview of bacterial virulence factors and pathogenesis. Biomed J. 2016;39:14-23.

2 Agin M, Batun I, Ozdemir S, Doran F, Tumgor G. Prevalence of Helicobacter pylori in Turkish children with celiac disease and its effect on clinical, histopathological, and laboratory parameters. Arch Med Sci. 2019;15:1475-1481.

3 Jones N, Chiba N, Fallone C, et al. Helicobacter pylori in First Nations and recent immigrant populations in Canada. Can J Gastroenterol. 2012;26:97-103.

4 Perez-Perez GI, Sack RB, Reid R, Santosham M, Croll J, Blaser MJ. Transient and persistent Helicobacterpylori colonization Native American children. J Clin Microbiol. 2003:41:2401-2407.

5 Center for disease control and prevention. Helicobacter pylori Fact Sheet for Health Care Providers. July 1998. Updated.

6 Watkins WM. The ABO blood group system: historical background. Transfus Med. 2001; $11: 243-265$

7 Sokic-Milutinovic A, Alempijevic T, Milosavljevic T. Role of Helicobacter pylori infection in gastric carcinogenesis: current knowledge and future directions. World $J$ Gastroenterol. 2015;21:11654-11672.

8 Shiota S, Murakawi K, Suzuki R, Fujioka T, Yamaoka Y. Helicobacter pylori infection in Japan. Expet Rev Gastroenterol Hepatol. 2013;7:35-40.

9 Bytzer P, Dahlerup JF, Eriksen JR, Jarbøl DE, Rosenstock S, Wildt S. Diagnosis and treatment of Helicobacter pylori infection. Dan Med Bull. April 2011;58(4):C4271. PMID 21466771. Archived from the original on 5 January 2014. Retrieved . Accessed August 7, 2013.

10 Floch P, Mégraud F, Lehours P. Helicobacter pylori strains and gastric MALT lymphoma. Toxins (Basel). 2017;9:132.
11 Goto Y, Syam AF, Darnindro N, Puspita Hapsari FC. Risk factors for and prevalence of Helicobacter pylori infection among healthy inhabitants in northern jakarta, Indonesia. Asian Pac J Cancer Prev APJCP. 2016;17:4469-4475.

12 Stenström B, Zhao CM, Rogers AB, et al. Swedish moist snuff accelerates gastric cancer development in Helicobacter pylori-infected wild-type and gastrin transgenic mice. Carcinogenesis. 2007;28:2041-2046.

13 Nseir W, Mograbi J, Di Castro N, et al. On the association between soft drink consumption and Helicobacter pylori infection [published correction appears in Dig Dis Sci. Dig Dis Sci. 2014 Oct;59(10):2605-2606, 2012;57:981-2606.

14 Contractor QQ, Tahir MY, Naseem S, Ahmad S. Helicobacter pylori in the dental plaque of healthy Saudis. Saudi J Gastroenterol. 1998;4:13-16.

15 Frérot M, Lefebvre A, Aho S, Callier P, Astruc K, Aho Glélé LS. What is epidemiology? Changing definitions of epidemiology 1978-2017. PLoS One. 2018;13, e0208442.

16 Khan J, Wahab A, Ameenullah, Kahn I, Afaq U. Seroprevalence of Helicobacter pylori infection among dyspeptic patients of Swat, Khyber Pakhtunkhwa, Pakistan. World J Pharm Sci. 2014;2:1925-1929.

17 Akeel M, Elmakki E, Shehata A, et al. Prevalence and factors associated with H. pylori infection in Saudi patients with dyspepsia. Electron Physician. 2018;10: 7279-7286.

18 Wang W, Jiang W, Zhu S, et al. Assessment of prevalence and risk factors of helicobacter pylori infection in an oilfield Community in Hebei, China. BMC Gastroenterol. 2019;14:186, 19.

19 Negash M, Wondifraw Baynes H, Geremew D. Helicobacter pylori infection and its risk factors: a Prospective cross-sectional study in resource-limited settings of northwest Ethiopia. Can J Infect Dis Med Microbiol. 2018. 2018, 9463710.

20 Rastogi M, Rastogi D, Singh S, Agarwal A, Priyadarshi BP, Middha T. Prevalence of Helicobacter pylori in asymptomatic adult patients in a tertiary care hospital: a cross sectional study. Biomed Res. 2015;26:117-122.

21 Shiferaw G, Abera D. Magnitude of Helicobacter pylori and associated risk factors among symptomatic patients attending at Jasmin internal medicine and pediatrics specialized private clinic in Addis Ababa city, Ethiopia. BMC Infect Dis. 2019;19:118.

22 Kouitcheu Mabeku LB, Noundjeu Ngamga ML, Leundji H. Potential risk factors and prevalence of Helicobacter pylori infection among adult patients with dyspepsia symptoms in Cameroon. BMC Infect Dis. 2018;18:278.

23 Massarrat S. Smoking and gut. Arch Iran Med. 2008;11:293-305.

24 Wu TC, Chen LK, Hwang SJ. Seroprevalence of Helicobacter pylori in school-aged Chinese in Taipei City and relationship between ABO blood groups. World $J$ Gastroenterol. 2003;9:1752-1755.

25 Ansari SA, Khan A, Khan TA, et al. Correlation of ABH blood group antigens secretion with Helicobacter pylori infection in Pakistani patients. Trop Med Int Health. 2015;20: 115-119.

26 Chakrani Z, Robinson K, Taye B. Association between ABO blood groups and Helicobacter pylori infection: a meta-analysis. Sci Rep. 2018;8:17604. 